\title{
TIPOLOGI RUANG PUBLIK PUSAT PERBELANJAAN (STUDI KASUS: SOLO GRAND MALL, SOLO PARAGON MALL, DAN SOLO SQUARE)
}

\section{Aulia Fatih Primadani \\ Program Studi Arsitektur Fakultas Teknik Universitas Muhammadiyah Surakarta e-mail: auliafatihprimadani@gmail.com}

\section{Nurhasan}

Program Studi Arsitektur Fakultas Teknik Universitas Muhammadiyah Surakarta e-mail: nur192@ums.ac.id

\begin{abstract}
ABSTRAK
Perkembangan kota-kota di Indonesia menyebabkan perubahan terhadap gaya hidup masyarakat. Akibatnya pusat perbelanjaan bertransformasi menjadi ruang publik perkotaan favorit menggantikan ruang terbuka publik kota yang sekarang mulai ditinggalkan oleh masyarakatnya. Oleh karena itu banyak unsur ruang publik yang dimasukkan ke dalam fungsi pusat perbelanjaan, sehingga terciptalah fasilitas-fasilitas yang bersifat publik. Bentuk dan lokasi peletakan ruang publik yang terdapat pada pusat perbelanjaan memiliki pola keteraturan yang sama. Pola yang sama dari ruang publik saling berkorelasi menghasilkan tipologi. Metode penelitian yang digunakan merupakan metode deskriptif kualitatif. Objek penelitian ini berpusat pada tiga pusat perbelanjaan di Kota Solo yaitu: Solo Grand Mall, Solo Paragon Mall, dan Solo Square. Hasil penelitian ini menunjukkan bahwa tipologi bentuk dan fungsi ruang publik pusat perbelanjaan ialah square atau melebar sebagai tempat melakukan kegiatan ditempat atau menetap dan linier atau melorong sebagai tempat sirkulasi atau kegiatan tidak menetap.
\end{abstract}

KATA KUNCI: ruang publik, tipologi, pusat perbelanjaan

\section{PENDAHULUAN}

Perkembangan kota-kota di Indonesia menyebabkan perubahan terhadap gaya hidup masyarakatnya. Masyarakat perkotaan memiliki gaya hidup yang cenderung lebih konsumtif. Gaya hidup inilah yang membuat masyarakat perkotaan membutuhkan suatu sarana baru yang dapat memenuhi kebutuhan gaya hidupnya. Ruang publik yang telah disediakan oleh pemerintah kota dinilai tidak memenuhi kebutuhan yang diinginkan untuk menunjang gaya hidup masyarakat konsumtif tadi. Faktor tidak terpenuhinya kebutuhan aktualisasi gaya hidup, akhirnya masyarakat mulai mencari tempat atau wadah baru yang digunakan sebagai penunjang gaya hidup mereka. Kemudian, mall atau pusat perbelanjaan yang menjadi pilihan terbaik bagi mereka.

Kota Surakarta atau lebih dikenal dengan sebutan Kota Solo menjadi salah satu kota yang sedang mengalami perkembangan itu. Banyak masyarakat Kota Solo yang menjadikan mall atau pusat perbelanjaan sebagai tempat atau wadah yang bukan hanya sekedar untuk transaksi jual beli melainkan telah menjadi lokasi bertemu, bertukar informasi, bahkan sebagai tempat untuk menunjukkan aktualisasi diri.

Mall atau pusat perbelanjaan bertransformasi menjadi ruang publik perkotaan favorit menggantikan ruang publik kota, yang sekarang mulai ditinggalkan oleh masyarakatnya. Meskipun demikian, mall atau pusat perbelanjaan tidak dapat seutuhnya menggantikan ruang publik kota karena tempat tersebut tetap menunjukan sifat eksklusif dan privat, dimana orang yang berkunjung cenderung berasal dari ekonomi kalangan tertentu dan tidak adanya kontak atau interaksi sosial yang terjadi. Kekurangan dan kecacatan pusat perbelanjaan sebagai ruang publik diambil sebagai peluang oleh para pengembang yang kemudian secara kreatif melakukan inovasi terhadap mall yang mereka kembangkan. Para pengembang memasukkan unsur-unsur ruang publik ke dalam fungsi pusat perbelanjaan sehingga terciptalah fasilitas yang bersifat publik.

Tempat yang bukan sepenuhnya publik ini menyediakan area-area yang dapat digunakan secara publik. Area ini biasanya terletak pada jalur-jalur yang umumnya memang digunakan pengunjung mall, misalnya area tempat duduk pada food court atau tempat bermain pada arena permainan. Bentuk dan lokasi peletakan ruang publik yang terdapat pada pusat perbelanjaan memiliki pola keteraturan yang sama. Pola yang sama dari ruang publik ini menjadi menarik untuk diteliti lebih dalam seberapa jauh keberadaan ruang publik itu dibutuhkan dalam mall.

Aspek-aspek yang saling berkorelasi tersebut dapat menghasilkan sebuah tipologi. Tujuan pengklasifikasian tipologi ini dapat membantu seorang arsitek kedepannya dalam merancang ruang publik 
yang ideal untuk mall atau pusat perbelanjaan. Dar hasil tipologi ini diharapkan seorang arsitek dapat lebih paham tentang bentuk-bentuk ruang publik dalam pusat perbelanjaan.

\section{KAJIAN PUSTAKA}

\section{Ruang Publik}

Ruang publik dapat diartikan sebagai ruang yang terbuka bagi semua orang untuk berkumpul dan berdiskusi tanpa mengkhawatirkan suatu hal apapun. Carr (1992) mengungkapkan bahwa ciri dari adanya ruang publik dapat ditandai dengan 3 hal yaitu: (a) responsif, yang bermakna bahwa ruang publik dapat digunakan untuk kepentingan luas; (b) demokratis, ialah ruang publik dapat digunakan oleh seluruh lapisan masyarakat umum dari berbagai latar belakang sosial, ekonomi, budaya serta aksesibel bagi berbagai kondisi fisik manusia; (c) bermakna, ialah ruang publik harus terintegrasi antara manusia, ruang, dan dunia luas dalam konteks sosial.

\section{Bentuk Ruang Publik}

Carmona (2003) menjelaskan bahwa ruang publik memiliki 3 macam bentuk menurut kegunaannya, yaitu:

\section{External Public Space}

Ruang publik jenis ini berada di luar ruang dan dapat diakses oleh semua orang, misalnya: alun-alun, taman kota, pedestarian, dan sebagainya.

2. Internal Public Space

Ruang publik jenis ini berada di dalam ruang dan dikelola oleh pemerintah, misalnya: kantor polisi, terminal, dan sebagainga.

\section{External and Internal 'Quasi' Public Space}

Ruang publik jenis ini berupa fasilitas umum yang dikelola oleh sektor privat dan memiliki beberapa aturan yang harus dipatuhi, misalnya: pusat perbelanjaan, taman hiburan, restoran, cafe.

Sementara itu Rob Krier (1979) mengutarakan bahwa ruang publik memiliki konsistensi bentuk berupa:

1. Ruang publik yang berbentuk square atau mengantong atau memusat

2. Ruang publik berbentuk street atau memanjang atau melorong

\section{Tipe dan Karakter Ruang Publik}

Carr (1992) mengungkapkan bahwa tipologi ruang publik terjadi karena penekanan kepada karakter kegiatannya, lokasi dan proses pembentuknya. Carr membagi tipologi ruang publik diantaranya adalah: jalan, taman bermain, jalur hijau, perbelanjaan dalam ruang, ruang spontan dalam lingkungan hunian, ruang terbuka komunitas, square dan plaza, pasar, dan tepi air.

\section{Ruang Publik Ideal}

Menurut Siahaan (2011) ruang publik yang ideal memiliki beberapa kriteria, antara lain:

1. Image dan Identity

Ruang publik atau yang sering dikaitkan dengan ruang terbuka harus memiliki sejarah dan identitas yang dapat menggambarkan suatu sejarah atau identitas suatu tempat. Adanya identitas memberi nilai lebih bagi tempat tersebut.

2. Atraksi dan Destinasi

Ruang publik hendaknya memiliki tempattempat yang memiliki daya tarik untuk memikat masyarakat agar mendatanginya. Daya tarik ini dapat berupa benda pasif (view, sarana dan prasarana) atau atraksi yang bersifat aktif.

3. Ketenangan

Ruang publik hendaknya memberi ketenangan bagi setiap penggunanya.

4. Desain yang fleksibel

Desain pada ruang publik harus fleksibel sehingga dapat dimanfaatkan oleh seluruh masyarakat dari berbagai kalangan umur.

\section{Pusat Perbelanjaan}

Dewasa ini pusat perbelanjaan sering dikaitkan dengan perkembangan sebuah kota. Hal ini menyebabkan pula perubahan gaya hidup masyarakat yang ada di dalamnya. Masyarakat menganggap pusat perbelanjaan merupakan fasilitas pokok yang perlu ada untuk melengkapi kebutuhan mereka. Marlina (2008) membagi klasifikasi pusat perbelanjaan sebagai berikut:

1. Pasar (market)

Pasar digunakan sebagai fasilitas perbelanjaan sederhana yang berada di suatu area tertentu pada suatu wilayah. Pasar dominan berlokasi pada area permukiman yang bersifat terbuka ataupun dalam ruangan. Sistem pengelolaan barang atau jasa pada pasar umumnya bersifat tradisional yaitu dengan transaksi tunai.

\section{Shopping Street}

Shopping street merupakan jenis sarana perbelanjaan yang terdiri dari deretan toko atau kios terbuka pada suatu penggal jalan. Shopping street berbentuk seperti pasar pada suatu jalan yang biasanya terletak pada kawasan-kawasan wisata.

\section{Shopping Precint}

Shopping precint merupakan jenis pusat perbelanjaan dengan kompleks pertokoan terbuka yang berorientasi pada suatu ruang terbuka bebas. Area perbelanjaan ini biasanya terletak pada objek kawasan wisata.

\section{Shopping Center}

Shopping center ialah pengelompokan fasilitas perbelanjaan yang berada di bawah satu atap. Berbeda dengan pasar yang dominan menyediakan 
barang primer, shopping center lebih kepada memperdagangkan barang yang bersifat sekunder dan tersier.

\section{Departement Store}

Departement store ialah wadah bagi penjualan eceran yang berskala besar. Tenaga pelayan dibutuhkan untuk transaksi dan membantu konsumen menemukan barang yang diinginkan.

\section{Supermarket}

Supermarket merupakan jenis pusat perbelanjaan yang menjual barang kebutuhan seharihari dengan cara pelayanan mandiri atau self service. Segala macam pencarian dan pemilihan produk dilakukan oleh konsumen secara mandiri. Pelayan hanya bertugas sebagai pembantu dalam proses pembayaran.

\section{Superstore}

Superstore merupakan jenis pusat perdagangan yang memiliki luas area penjualan lebih dari $2.500 \mathrm{~m} 2$. Biasanya superstore menempati satu lantai pada bangunan yang terletak pada pusat kota.

8. Hypermarket

Hypermarket merupakan istilah dari perluasan superstore dengan luas minimum $5.000 \mathrm{~m} 2$. Hypermarket menyediakan barang yang sangat bermacam-macam dan memiliki kecenderungan mengikuti tren yang sedang berkembang dalam kota. Barang yang disediakan pun dapat berupa eceran maupun grosir.

\section{Shopping Mall}

Dalam bahasa Indonesia mall dapat diartikan sebagai sekumpulan plaza, jalan, belokan yang dirancang khusus untuk pejalan kaki (Ruberstain, 1978). Mall dapat disebut sebagai jalan pada pusat usaha yang berbeda dengan lalu lintas umum tetapi memilki akses yang mudah serta digunakan sebagai tempat berjalan-jalan, ataupun sekedar duduk-duduk untuk bersantai. Keberadaan ruang publik pada shopping mall merupakan pembeda dari pusat perbelanjaan yang lain.

\section{Town Square}

Town square merupakan jenis pusat perbelanjaan tingkat internasional yang dilengkapi dengan area rekreasi independen dengan fasilitas penunjang sesuai dengan kebutuhan pasar.

\section{Ruang Publik Pusat Perbelanjaan}

Pusat perbelanjaan tidak dapat menjadi ruang publik yang utuh. Hal ini telah banyak dibahas oleh penelitian-penelitian sebelumnya. Pusat perbelanjaan hanya dapat dijadikan sebagai tempat berkumpul dan rekreasi bukan ruang publik yang membebaskan seseorang untuk mengemukakan pendapatnya karena pusat perbelanjaan tersebut milik Penulis, 2019 bukan pemerintah.

Namun keberadaan ruang publik pada pusat perbelanjaan juga sangat dibutuhkan. Ruang publik yang baik akan mendatangkan pengunjung yang lebih banyak. Ruang publik ini juga dijadikan salah satu tolak ukur para pengunjung dalam memilih pusat perbelanjaan. Karena pada zaman ini pusat perbelanjaan bukan hanya tempat untuk melakukan transaksi namun lebih dari itu pusat perbelanjaan telah bertransformasi sebagai tempat rekreasi atau sekedar berkumpul dengan keluarga atau rekan.

\section{METODE PENELITIAN}

Metode penelitian yang digunakan adalah deskriptif kualitatif, dengan metode pencarian data melalui observasi dan survey. Penelitian ini dilakukan dengan membuat gambaran dari sebuah peristiwa dan menggalinya secara mendalam dan nyata.

\section{Pemilihan Lokasi}

Objek observasi untuk pengklasifikasian tipologi ruang publik pusat perbelanjaan dilakukan ditiga mall besar di Kota Surakarta yaitu Solo Grand Mall, Solo Paragon Mall dan Solo Square. Pemilihan tiga objek ini didasari oleh ketenaran atau kemasyhuran yang sudah sangat dikenal oleh masyarakat Solo dan sekitarnya.

\section{ANALISIS DAN PEMBAHASAN}

\section{Denah dan Titik Lokasi Ruang Publik Pusat Perbelanjaan}

Peneliti memetakan denah dengan membedakan bentuk ruang publik yang ada di setiap pusat perbelanjaan. Gambar 1 sampai 3 menunjukkan denah dari tiga lokasi penelitian, yang masing-masing diberi tanda untuk memperjelas analisis. Garis putus-putus (merah) memiliki arti bahwa ruang publik tersebut berada diantara pertokoan dan berfungsi sebagai jalur sirkulasi pengunjung. Sedangkan blok (kuning) menandakan ruang publik yang lebih lapang dan difasilitasi dengan tempat duduk.

\section{Solo Grand Mall}

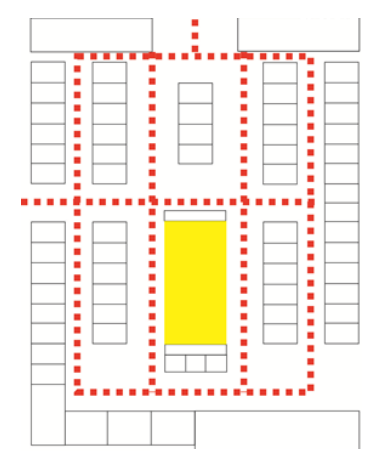

(a)

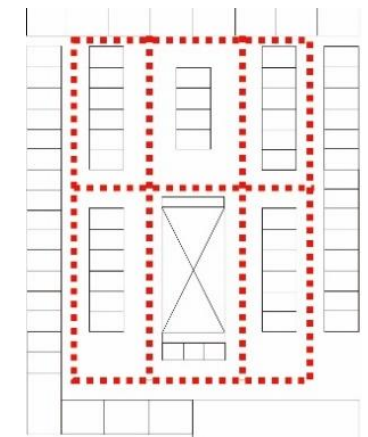

(b) 


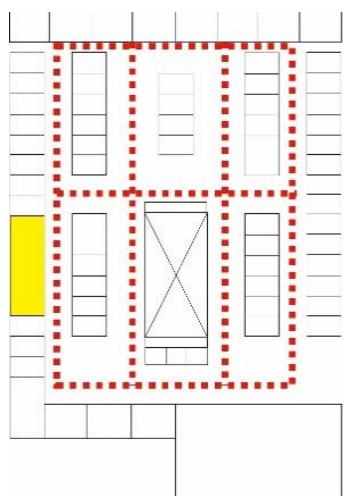

(c)

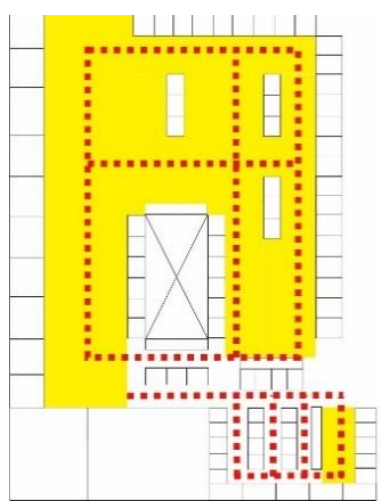

(d)
Gambar 1. Denah Solo Grand Mall (a)ground floor, (b) lantai 1, (c) lantai 2 dan (d) lantai 3 (sumber: dokumen penulis, 2019)

\section{Solo Paragon}

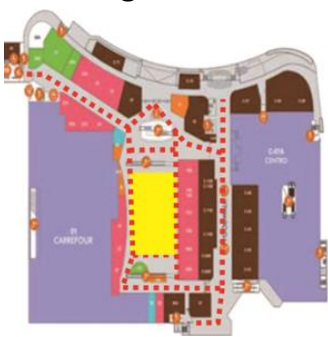

(a)

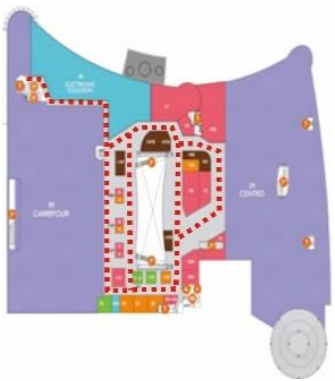

(c)

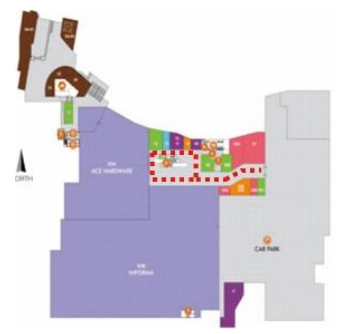

(b)

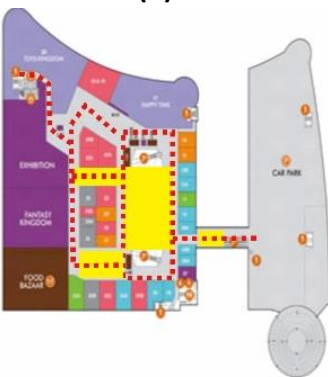

(d)
Gambar 2. Denah Solo Paragon (a) lower ground, (b) ground floor, (c) upper ground dan (d) denah FF (sumber: dokumen penulis, 2019)

\section{Solo Square}

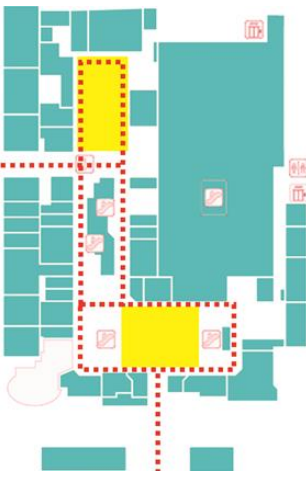

(a)

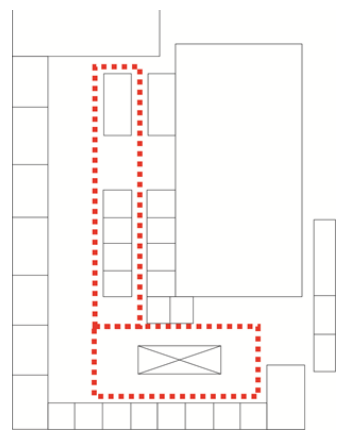

(b)

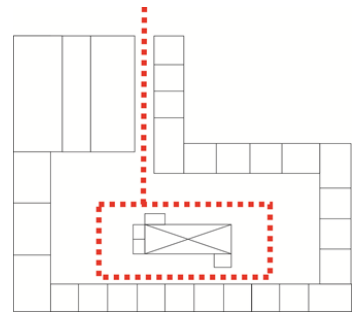

(c)

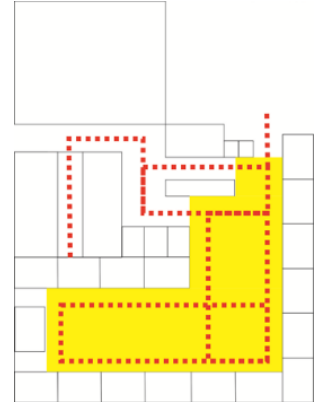

Gambar 3. Denah Solo Square (a) ground floor, (b) lantai 1, (c) lantai 2 dan (d) lantai 3 (sumber: dokumen penulis, 2019

\section{Bentuk Ruang Publik Pusat Perbelanjaan}

Table 1. Bentuk Ruang Publik Pusat Perbelanjaan di Solo Grand Mall

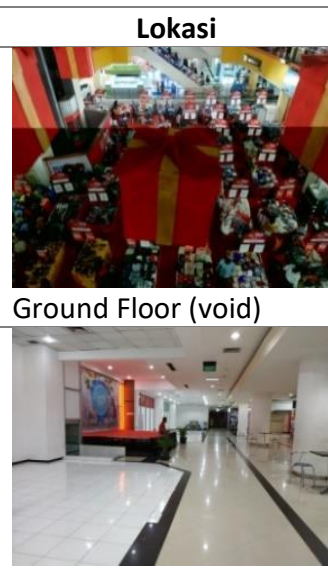

Lantai 1. Tempat

tersembunyi (sirkulasi belakang pertokoan)

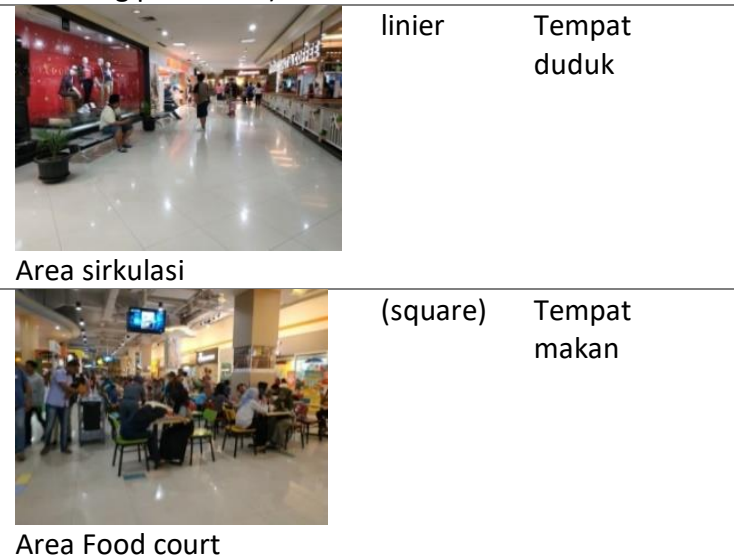

Area Food court

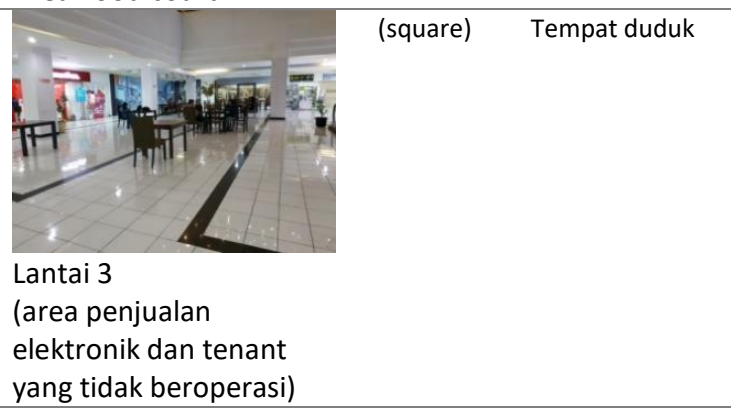

(Sumber: Analisa Penulis, 2019) 
Table 2. Bentuk Ruang Publik Pusat Perbelanjaan di Solo Paragon Mall

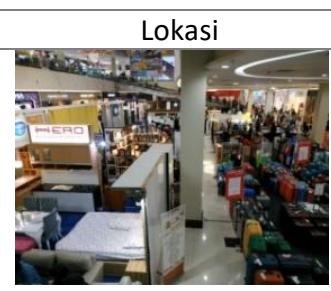

\begin{tabular}{cl} 
Bentuk & \multicolumn{1}{c}{ Fungsi } \\
(square) & Tempat \\
& pementasan, \\
& pameran, \\
& festival, \\
& perlombaan, \\
& bazar
\end{tabular}

LG (void)

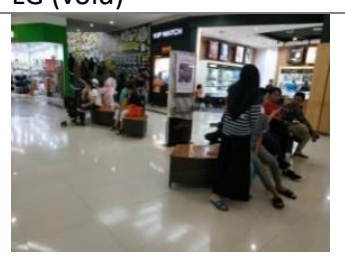

(linier) Tempat

duduk

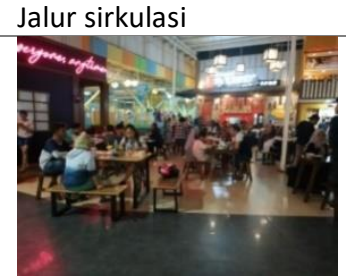

(square) Tempat

makan

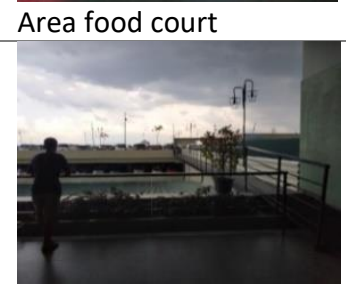

(square) Tempat menikmati view outdoor

Area outdoor

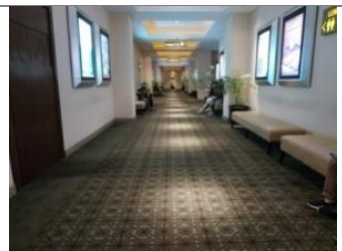

(linier) Tempat

tunggu

bioskop

Area bioskop

(Sumber: Analisa Penulis, 2019)

Table 3. Bentuk Ruang Publik Pusat Perbelanjaan di Solo Square Mall

\begin{tabular}{lll}
\hline Lokasi & Bentuk & \multicolumn{1}{c}{ Fungsi } \\
\hline (square) & $\begin{array}{l}\text { Tempat } \\
\text { pementasan, } \\
\text { pameran, } \\
\text { festival, } \\
\text { perlomban, } \\
\text { bazar }\end{array}$ \\
\hline Jalur sirkulasi & (linier) & $\begin{array}{l}\text { Tempat } \\
\text { tunggu }\end{array}$ \\
& & \\
\hline
\end{tabular}

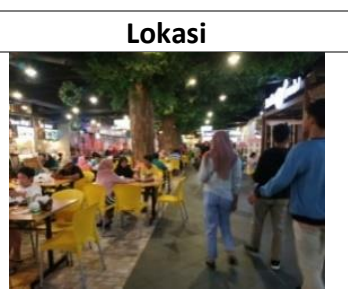

$\begin{aligned} \text { Bentuk } & \text { Fungsi } \\ \text { (square) } & \begin{array}{l}\text { Tempat } \\ \text { makan }\end{array}\end{aligned}$

Area foodcourt

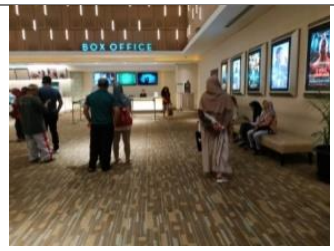

(linier) Tempat

tunggu

bioskop

Area bioskop

(Sumber: Analisa Penulis, 2019)

\section{Klasifikasi Pusat Perbelanjaan}

Table 4. Klasifikasi Pusat Perbelanjaan

\begin{tabular}{ll}
\hline \multicolumn{1}{c}{$\begin{array}{c}\text { Nama Pusat } \\
\text { Perbelanjaan }\end{array}$} & \multicolumn{1}{c}{ Klasifikasi } \\
\hline Solo Grand Mall & $\begin{array}{l}\text { Departement Store } \\
\text { Supermarket } \\
\text { Departement Store } \\
\text { Supermarket } \\
\text { Departement Store } \\
\text { Supermarket }\end{array}$ \\
Solo Square & \\
\hline
\end{tabular}

(Sumber: Analisa Penulis, 2019)

Jadi walaupun ketiga pusat perbelanjaan tersebut terkenal dengan sebutan mall tetapi dalam bahasa keilmuan bernama atau termasuk dalam departement store dan supermarket.

\section{Bentuk Ruang Publik Pusat Perbelanjaan}

Ruang publik khususnya pada pusat perbelanjaan memiliki bentuk yang sangat beragam. Bentuk dari ruang publik ini sangat dipengaruhi oleh jenis kegiatan yang dilakukan di dalamnya. Beberapa macam bentuk ruang publik:

\section{Square atau melebar}

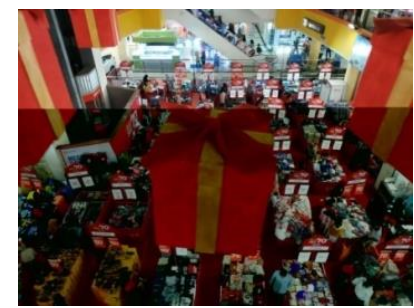

Gambar 1. Bentuk Square

(Sumber: Analisa Penulis, 2019)

Bentuk square ruang publik pada pusat perbelanjaan memiliki kesamaan letak yaitu pada titik atau void pusat perbelanjaan. Jenis kegiatan yang dilakukan pun sangat beragam, yaitu: tempat pementasan, pameran, festival, perlombaan, dan 
acara lainnya. Bentuk ruang publik jenis ini memiliki fungsi temporal, yaitu akan selalu berubah sesuai dengan kebutuhannya.

Bentuk square ruang publik lainnya dapat ditemukan pada area food court. Meskipun area ini terlihat seperti terpisah-pisah namun sesungguhnya memiliki satu kesatuan dan berada dalam satu lingkup yang sama yaitu dikelilingi oleh kios-kios makanan.

\section{Linier}

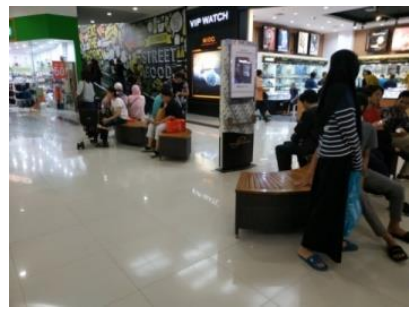

Gambar 2. Linier atau Melorong

(Sumber: Analisa Penulis, 2019)

Bentuk linier terdapat pada ruang publik yang berlokasi di area sirkulasi. Ruang publik ini akan mengikuti arus dari sirkulasi sehingga membentuk linier. Bentuk ini biasanya berada di antara kios-kios yang saling berhadapan.

Bentuk linier ini juga memiliki konsistensi jika di tengahnya terdapat tempat duduk, maka jalur atau area tersebut lebih ramai dibandingkan jalan atau jalur yang tidak dilengkapi dengan tempat duduk.

\section{Fungsi Ruang Publik Pusat Perbelanjaan}

Pembahasan tipologi bentuk ruang publik sebelumnya sangat berkaitan dengan tipologi fungsi yang ada. Bentuk yang dihasilkan merupakan penyesuaian dari fungsi yang dibutuhkan. Adapun tipologi fungsi ruang publik pusat perbelanjaan berupa:

1. Tempat berkumpul atau melakukan kegiatan di tempat tersebut

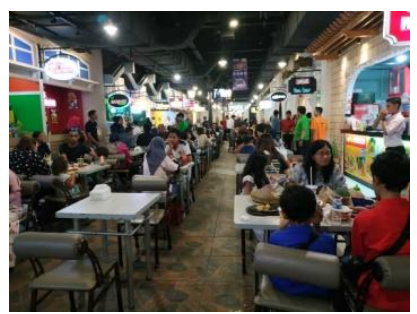

Gambar 3. Ruang publik dengan pengguna yang menetap

(Sumber: Analisa Penulis, 2019)

2. Tempat sirkulasi atau tidak menetap pada satu tempat

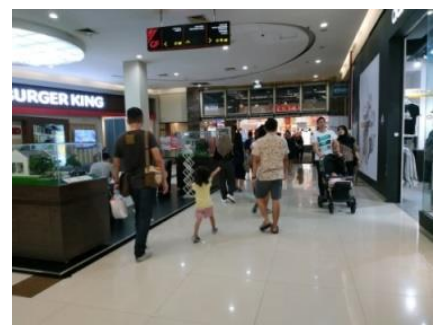

Gambar 4. Ruang publik dengan pengguna yang selalu bergerak atau tidak menetap

(Sumber: Analisa Penulis, 2019)

\section{Ruang Publik Pusat Perbelanjaan Paling Diminati}

Hasil pengolahan data dan analisa dapat diketahui bahwa ruang publik yang paling diminati ialah ruang publik yang bebentuk square. Ruang publik dengan bentuk square memiliki ruang gerak yang lebih leluasa terlebih yang di dalamnya terdapat fasilitas tempat duduk dan dikelilingi kios-kios yang menjual makanan seperti yang terdapat pada area food court.

Walaupun ruang publik dengan bentuk square lebih diminati akan tetapi bentuk linier juga sangat perlu diperhatikan. Bentuk sirkulasi yang terlalu sempit dan membentuk lorong yang terlalu panjang akan membuat pengunjung enggan untuk melewati tempat tersebut. Sebaliknya, jika sirkulasi memiliki akses yang lebar bahkan terdapat fasilitas tempat duduk maka pengunjung akan senang melewati tempat tersebut.

\section{KESIMPULAN}

Berdasarkan hasil pengamatan yang dilakukan di lapangan, maka dapat disimpulkan sebagai berikut:

1. Solo Grand Mall, Solo Paragon Mall, dan Solo Square merupakan pusat perbelanjaan yang memiliki klasifikasi sebagai departement store dan supermarket

2. Tipologi bentuk ruang publik pada ketiga pusat perbelanjaan tersebut ialah square dan linier

3. Tipologi fungsi ruang publik pada ketiga pusat perbelanjaan tersebut ialah sebagai tempat berkumpul dengan melakukan kegiatan di tempat atau menetap dan sebagai tempat sirkulasi atau kegiatan tidak menetap

4. Ruang publik yang paling diminati oleh pengunjung ialah ruang publik square yang dapat digunakan sebagai tempat berkumpul dan melakukan kegiatan ditempat serta fasilitasi dengan tempat duduk.

\section{DAFTAR PUSTAKA}

Carmona, et al.( 2003). Public Places - Urban Spaces, The Dimension of Urban Design, Boston, MA : Architectural Press 
Carr Stephen, dkk. (1992). Public Space. USA: Combridge University Press

Krier, Rob. (1979). Urban Space, London: Academy Editions,

Maitland, Barry. (1985). Shopping Mall: Planning and Design, New York: Langman Group Limited

Marlina, Endy.(2008). Panduan Perancangan Bangunan Komersial, Yogyakarta, Penerbit Andi

Ruberstain Harvey. (1978). Central City Mall, New York: A. Willey Interscience Publication

Siahaan, James. (2011). Ruang Publik: Antara Harapan dan Kenyataan. Buletin Tata Ruang, Edisi Juli-Agustus 2010, pp: 133-147 